\title{
LIST OF THE DOCTORS HONORIS CAUSA
}

1 - Prof. Dr. h. c. mult. Erik Jayme, University of Heidelberg, German. International Law and Comparative Law (Laudatio Prof. Dr. Claudia Lima Marques) - 2003

2 - Prof. Dr. Miguel Reale, University of São Paulo, Brazil . Legal Theory and Filosophy of Law (Laudatio Prof. Dr. Judith Martins Costa) 2003

3 - Prof. Eduardo Garcia de Enterrìa, University Complutense of Madrid, Spain. Administrative Law and Legal Theory (Laudatio Prof. Dr. Cezar Saldanha de Souza Jr) $-2003$

[2004 - Prof. Paolo Grossi, University of Florence, Italy] 